\title{
Pelagic food web structure and carbon budget in the northern Baltic Sea: potential importance of terrigenous carbon
}

\author{
J. Sandberg ${ }^{1, *}$, A. Andersson ${ }^{2,3}$, S. Johansson ${ }^{4}$, J. Wikner ${ }^{3}$ \\ ${ }^{1}$ Department of Systems Ecology, Stockholm University, 10691 Stockholm, Sweden \\ ${ }^{2}$ Marine Ecology, Dept. of Ecology and Environmental Science, Umeå University, 90185 Umeå, Sweden \\ ${ }^{3}$ Umeå Marine Sciences Centre, Umeå University, 91020 Hörnefors, Sweden \\ ${ }^{4}$ Swedish Environmental Protection Agency, 10648 Stockholm, Sweden
}

\begin{abstract}
The objective of this study was to quantitatively assess the relative importance of terrigenous dissolved organic material (TDOC) as a carbon source for secondary producers (e.g. bacteria) and as a structuring factor for the pelagic food web in the Gulf of Bothnia, northern Baltic Sea. The 3 study sites, situated in Bothnian Bay (BB), the Öre Estuary (ÖE) and the Bothnian Sea (BS), had markedly different freshwater loads and water-residence times. In Bothnian Bay, bacterial biomass and production were higher than expected from the levels of phytoplankton biomass and productivity there, suggesting an uncoupling of bacterial productivity from phytoplankton production. Phytoplankton size structure and size-fractionated production were, however, relatively similar among areas. A simplified carbon budget model suggested that bacterioplankton dominated organic carbon consumption in all of the food webs studied, but was most marked in BB. The model showed that the available autochthonous primary production could not alone support the heterotrophic carbon demand in BB. The most likely explanation of this discrepancy was that the total annual input of terrigenous dissolved organic carbon was bioavailable, resulting in a budget closer to balance with the heterotrophic carbon demand. $\mathrm{BB}$, receiving $38 \%$ of the carbon input from land, was consequently a net heterotrophic ecosystem. A sensitivity analysis showed that the bacterial carbon demand, and growth efficiency in particular, had the greatest influence on the resulting budget. TDOC was the dominant carbon source in ÖE, but the losses of carbon through advection to offshore areas and sedimentation was high. The evidence of net heterotrophy in ÖE was therefore weaker than in BB. In BS the input of TDOC was less important, and the carbon used for secondary production originated mainly from autochthonous primary production. Our results suggest that the supply of TDOC is of great importance for the abundance of plankton and as a structuring factor for the aquatic food webs in the Gulf of Bothnia.
\end{abstract}

KEY WORDS: Food web · Heterotrophy · Bacteria · Terrigenous · Carbon · Model · Baltic Sea Resale or republication not permitted without written consent of the publisher

\section{INTRODUCTION}

On a global scale, allochthonous carbon of terrigenous origin has been suggested to significantly contribute to the supply of reduced organic carbon to the sea (Smith \& Mackenzie 1987). This insight is part of an ongoing revision of the traditional view that humic riverine organic carbon is not a readily available (recalcitrant) carbon source to the marine food web. This revision of the importance of terrigenous organic carbon is further nurtured by evidence that allochthonous organic matter can support the growth of secondary producers in lakes (Tranvik \& Höfle 1987, Salonen et al. 1992), streams (Leff \& Meyer 1991) and coastal waters (Carlsson \& Granéli 1993, Moran \& Hodson 1994). Secondary producers in coastal waters 
may be promoted by the increase in bioavailability when terrestrial dissolved organic matter (DOM) enters estuarine environments (Stepanauskas et al. 1999, Wikner et al. 1999). Photochemical oxidation of humic substances may further promote their biological utilisation (Kieber et al. 1990).

Spatial differences in the relative contribution of terrigenous dissolved organic matter (TDOC) and indigenous primary production as sources of energy to secondary production may affect overall food web structure and processes in aquatic ecosystems. For instance, in aquatic ecosystems with low phytoplankton carbon fixation ( $<70$ to $\left.120 \mu \mathrm{g} \mathrm{C} \mathrm{dm}^{-3} \mathrm{~d}^{-1}\right)$, bacterial respiration exceeds net primary production (del Giorgio et al. 1997), and total community respiration exceeds gross primary productivity (Duarte \& Agusti 1998). Secondary producers in such ecosystems, e.g. bacteria, are thus thought to require external inputs of organic carbon in order to support the estimated net heterotrophy of the system. Similarly, in lakes the relative supply of organic carbon from autochthonous or allochthonous sources to secondary producers may determine the degree of recycling of nutrients and materials (Jansson 1998) and the transfer efficiency of energy to higher trophic levels in food webs (Hessen 1998).

In the Baltic Sea, indigenous phytoplankton carbon fixation has been estimated to constitute the major carbon input to secondary producers (Elmgren 1984). However, variations in the carbon budget exist between the major basins of the Baltic. The northernmost basin (Bothnian Bay [BB]; $1417 \mathrm{~km}^{3}$ ) is characterised by a 3-fold higher freshwater discharge per volume than the adjacent Bothnian Sea $\left(\mathrm{BS} ; 817 \mathrm{~km}^{3}\right)$. This creates a clear difference in the load of TDOC to the basins, as well as a relatively stable salinity gradient, which ranges from 2 psu in the north to 7 psu in the south. Furthermore, measurements show lower phytoplankton carbon production, lower phosphate and higher nitrate concentrations in BB than in BS. Several studies suggest that the input of TDOC may explain (1) the high biomass and productivity of mesozooplankton relative to primary production in the Gulf of Bothnia (Ackefors et al. 1978), (2) that bacterial carbon demand exceeds autochthonous primary production in a coastal area (Öre Estuary; ÖE) (Zweifel et al. $1995)$ and (3) that 15 to $37 \%$ of the mesozooplankton biomass in $\mathrm{BB}$ could be attributed to consumption of prey utilising TDOC (Rolff \& Elmgren 2000). In other areas of the Baltic, such as the Gulf of Finland, TDOC has also been suggested as a potentially important source of carbon to meet heterotrophic carbon demand in the pelagic food web during spring (Lignell et al. 1993) and summer (Uitto et al. 1997) conditions. Especially in the eastern part of the Gulf of Finland, the high input of organic material from the River Neva has been addressed as an important factor influencing trophic conditions in that area (Pitkänen et al. 1993). Also, in the northernmost Gulf of Bothnia, the relative importance of TDOC to bacteria and the heterotopy of the ecosystem have been studied (Zweifel et al. 1995, (Wikner \& Hagström 1999). However, none of these studies have directly and quantitatively addressed the relative importance of TDOC for the whole pelagic carbon budget covering a full seasonal cycle.

The objective of this study was to quantitatively assess the relative importance of TDOC as a carbon source for secondary producers in the pelagic food web in the Gulf of Bothnia. Our working hypothesis was that areas with a high contribution of riverine organic carbon and long residence time should present an uncoupling of bacterio- and phytoplankton productivity, similar to the suggestion for zooplankton (Ackefors et al. 1978, Rolff \& Elmgren 2000). If bacterial production were uncoupled from primary production, it would suggest a relatively higher importance of heterotrophic processes compared to areas with low external energy inputs of carbon. In order to explore these questions, TDOC data and biological variables in the pelagic zone, gathered during the 'Gulf of Bothnia year 1991' at 3 sites with markedly different freshwater load and residence time (BB, ÖE and BS), were used. In the 'Discussion', we present a hypothetical model of how carbon at the bottom of the food web, e.g. primary producers, TDOC and bacteria, is used and allocated to higher trophic levels in the pelagic food web, and we highlight the importance of TDOC for food web structure and processes in the Gulf of Bothnia.

\section{MATERIALS AND METHODS}

The sampled stations A13 (Bothnian Bay; 64 ${ }^{\circ} 42.50^{\prime} \mathrm{N}$; $22^{\circ} 04.00^{\prime} \mathrm{E}$ ), C1 (Bothnian Sea; 62 $2^{\circ} 35.22^{\prime} \mathrm{N}_{i} 19^{\circ} 58.41^{\prime} \mathrm{E}$ ) and B3 (Öre Estuary [ÖE]; $63^{\circ} 29.98^{\prime} \mathrm{N}$; $19^{\circ} 49.14^{\prime} \mathrm{E}$ ) are shown in Fig. 1. Data on size-fractionated phytoplankton biomass data have already been presented in Andersson et al. (1996), whereas bacterial biomass and productivity data are available in Zweifel et al. (1995) and Wikner \& Hagström (1999). In this study, these data were complemented with data on sedimentation, the biomass of 3 size classes of flagellates and zooplankton, as well as calculated zooplankton productivity measured during 1991. The relative importance of TDOC for bacteria and other heterotrophs in the pelagic food web is discussed primarily from measured data, but also in terms of a simplified carbon budget presented in the 'Discussion'.

Viruses. Virus production data were derived from literature values reported by Steward et al. (1993). 
Hydrographic data, DOC, bacterial biomass and production. Hydrographic and morphometric data, such as mean and maximum depths, total volume, ice coverage, and freshwater- and DOC discharge for each area were taken from Wikner \& Hagström (1999) (Table 1), as well as data on water temperature, salinity and light irradiation measurements (Table 2). Data on bacterial biomass and productivity, as well as methodology used, are also available in Wikner \& Hagström (1999). In this study, those values were integrated over the average water column in each area (Table 1). Bacterioplankton samples were collected from the depths of $0,4,8,14,20,40,60,80$ and $100 \mathrm{~m}$.

Sedimentation. Sediment traps with parallel replaceable tubes (with a height:diameter ratio of 5) were used. The mooring system was based on an anchor, a buoy with a flag and radar reflector and a free-floating trap at a fixed depth. The tubes were maintained in a vertical position with gimbal suspension (Larsson et al. 1986). Sediment traps (winter traps) used during the ice-cover period were equipped with one tube instead of parallel tubes, and a mooring system without a surface buoy; instead of pulling the trap up from the surface, it was dragged up. At B3 the traps were placed at a depth of $14 \mathrm{~m}$, and at $30 \mathrm{~m}$ for Stns A13 and C1.

The sediment traps were replaced every 2 wk from May to December in BS and June to November in BB. The rest of the year the traps were replaced once a

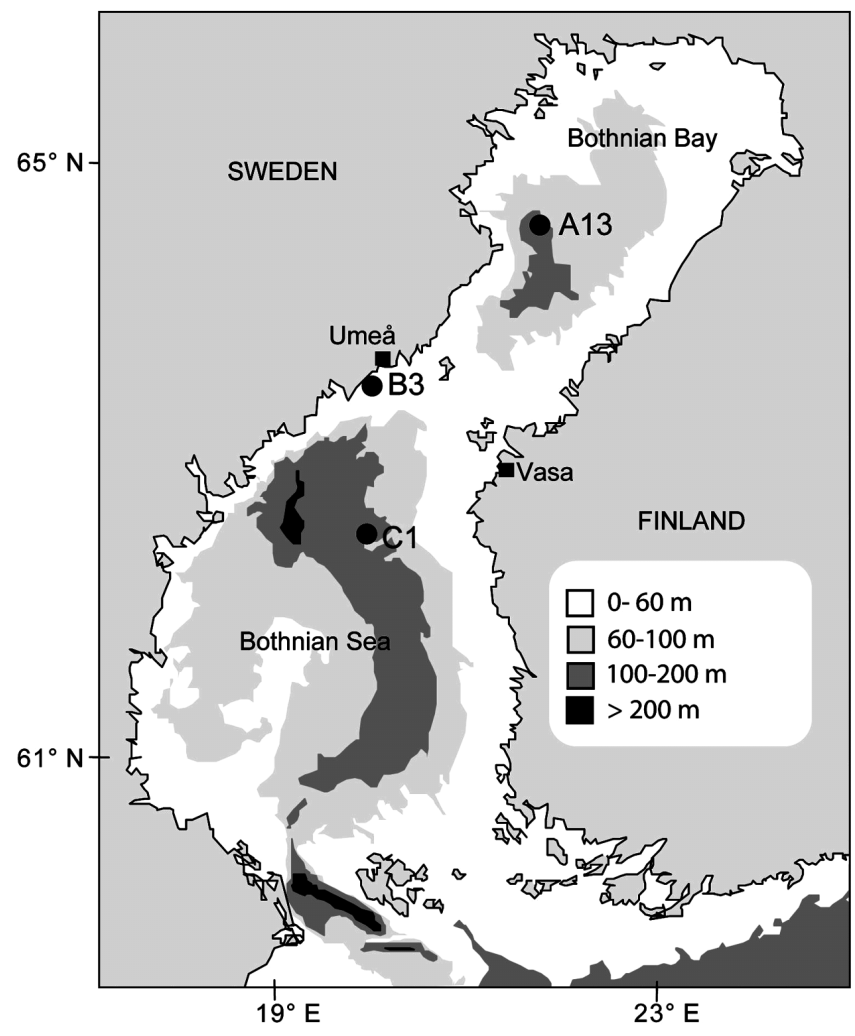

Fig. 1. Map of the Gulf of Bothnia showing sampling stations. Station names are according to the nomenclature of the station network of the Helsingfors Commission (HELCOM 2002)
Table 1. Morphometric and hydrographic data of the study sites in the Gulf of Bothnia. Morphometric values, ice coverage and freshwater discharge from HELCOM (1990) and Forsgren \& Jansson (1992). Discharge of dissolved organic carbon (DOC) to the Öre Estuary is based on Pettersson et al. (1997)

\begin{tabular}{|c|c|c|c|c|c|c|}
\hline Stn & $\begin{array}{l}\text { Mean } \\
\text { depth } \\
\text { (m) }\end{array}$ & $\begin{array}{l}\text { Max. } \\
\text { depth } \\
\text { (m) }\end{array}$ & $\begin{array}{l}\text { Volume } \\
\left(\mathrm{km}^{3}\right)\end{array}$ & $\begin{array}{l}\text { Ice } \\
\text { cover } \\
\text { (wk) }\end{array}$ & $\begin{array}{l}\text { Freshwater } \\
\text { discharge } \\
\left(\mathrm{km}^{3} \mathrm{yr}^{-1}\right)\end{array}$ & $\begin{array}{c}\text { DOC } \\
\text { discharge } \\
\left(\mathrm{mmol} \mathrm{C} \mathrm{dm}^{-2} \mathrm{yr}^{-1}\right)\end{array}$ \\
\hline A13 (BB) & 41 & 146 & 1481 & 4 & 98 & 18 \\
\hline B3 (ÖE) & 16 & 33 & 1.0 & 6 & 1.2 & 208 \\
\hline C1 (BS) & 66 & 294 & 4308 & 0 & 95 & 7.7 \\
\hline
\end{tabular}

Table 2. Temperature, salinity and light influx (mean and range) during 1991 at the 3 sampling stations. Temperature and salinity are annual averages in the depth interval, and light influx is the integrated average in the 0 to $20 \mathrm{~m}$ surface layer. Data are given separately for the depth intervals 0 to $20 \mathrm{~m}$ and 20 to $100 \mathrm{~m}$

\begin{tabular}{|lrlcc|}
\hline Stn & & \multicolumn{1}{c}{$\begin{array}{c}\text { Temperature } \\
\left({ }^{\circ} \mathrm{C}\right)\end{array}$} & \multicolumn{1}{c}{$\begin{array}{c}\text { Salinity } \\
(\%)\end{array}$} & $\begin{array}{c}\text { Light influx } \\
\left(\mu \mathrm{E} \mathrm{m}^{-2} \mathrm{~s}^{-1}\right)\end{array}$ \\
\hline A13 (BB) & $0-20 \mathrm{~m}$ & $6.8(-0.1$ to 18.0$)$ & $3.2(2.9$ to 3.4$)$ & $33(0.7$ to 91$)$ \\
& $20-100 \mathrm{~m}$ & $2.4(-0.1$ to 10.3$)$ & $3.6(3.5$ to 3.7$)$ & - \\
B3 (ÖE) & $0-20 \mathrm{~m}$ & $6.6(-0.2$ to 17.3$)$ & $4.3(1.2$ to 5.7$)$ & $93(0.6$ to 283$)$ \\
& $20-25 \mathrm{~m}$ & $4.3(0.0$ to 7.4$)$ & $5.2(4.8$ to 5.5$)$ & - \\
C1 (BS) & $0-20 \mathrm{~m}$ & $7.8(1.0$ to 18.3$)$ & $5.4(3.5$ to 5.9$)$ & $151(6.4$ to 440$)$ \\
& $20-100 \mathrm{~m}$ & $3.3(1.0$ to 8.6$)$ & $6.0(4.2$ to 6.4$)$ & - \\
\hline
\end{tabular}

month. Winter traps were set out in December, and replaced when the station became ice-free (April or May). To stop breakdown of organic material during the exposure period, $3 \mathrm{ml}$ of chloroform was added into each tube. When collecting the tubes, the water column was decanted from the sediment and then sediment was centrifuged $(20400 \times g$ at $r_{\max }, 10$ to $15 \mathrm{~min}$, at $4^{\circ} \mathrm{C}$ ) and freezedried. The dry weight was corrected for the salt content of the seawater remaining in the sediment, and the result given to the nearest $0.1 \mathrm{mg}$.

Phosphorus, iron and aluminium were determined by inductively coupled plasma-atomic emission spectroscopy (ICP-AES). Sediments were fused with lithium metaborate at $960^{\circ} \mathrm{C}$ and subsequently dissolved in nitric acid (Boumans 1987). Certified reference materials from the National Research Council of Canada were used for standardisation. Analyses of carbon and nitrogen in sediments were per- 
formed with a Carlo Erba Model 1106 high-temperature combustion elemental analyser, using standard procedures. Acetanilide was utilised for standardisation. Sedimentation was corrected for resuspension according to Blomqvist \& Larsson (1994).

Phytoplankton biomass and productivity. The methodology for and seasonal dynamics of phytoplankton $>10 \mu \mathrm{m}$, between 2 and $10 \mu \mathrm{m}$, and $<2 \mu \mathrm{m}$ have been presented in Andersson et al. (1996). As described there, the phytoplankton was collected with a $20 \mathrm{~m}$ plastic hose $(\varnothing 2.5 \mathrm{~cm})$ and preserved with Lugol's solution and formaldehyde (2\% final conc.). Eukaryotic phytoplankton was identified using the Utermöhl technique. Cyanobacteria were collected on $0.2 \mu \mathrm{m}$ polycarbonate filters and counted by epifluorescence microscopy. At least 500 eukaryotic algal and 300 cyanobacterial cells were counted per slide.

Phytoplankton biomass was calculated via determined biovolumes and published relations (Strathmann 1967, Verity et al. 1992) between biovolume and carbon content for pico- and nanoplankton, diatoms and other microplankton, as described by Andersson et al. (1996). The SD for the phytoplankton estimates were $\pm 27 \%$ (algae $>10 \mu \mathrm{m}), \pm 18 \%$ (2 to $10 \mu \mathrm{m}$ algae) and $\pm 6 \%$ (cyanobacteria) (Andersson \& Rudehäll 1993). Under the thermocline, values were based on the results from 2 profiles of phytoplankton conducted down to $100 \mathrm{~m}$ (data not shown), assuming a similarly low occurrence year-round.

In this study phytoplankton photosynthesis was determined by ${ }^{14} \mathrm{C}$ bicarbonate techniques (Gargas 1975, Larsson \& Hagström 1982, Andersson et al. 1996). Radioactive carbonate $\left(6 \mu \mathrm{Ci}, 0.1 \mathrm{mCi} \mathrm{mmol}^{-1}\right)$ was added to samples collected from depths of $0,1,2$, $4,6,8,10,14$ and $20 \mathrm{~m}$ and incubated in situ for 3 to $4 \mathrm{~h}$ around noon. The incorporation of the isotope into whole water was determined in $5 \mathrm{ml}$ acidified sub- samples. Incorporation into size fractions was determined by post-filtration through 10, 2, 0.6 and $0.2 \mu \mathrm{m}$ polycarbonate filters (MSITM) at $100 \mathrm{~mm} \mathrm{Hg}$. Values were transformed to daily rates after multiplying by the ratio of daily irradiation to insolation during the incubation period (Andersson et al. 1996). The squared sum SD of light and dark triplicates was determined to average $\pm 52 \%(\mathrm{n}=30)$, with a substantial variation in SD between the samples.

Protozooplankton. Flagellate abundance was determined from integrated samples taken with the $20 \mathrm{~m}$ hose. Flagellates reported in the literature to be potential phagotrophs (whether strictly heterotrophic or mixotrophic) were identified by inverted microscopy in Lugol-preserved samples as described for phytoplankton. The phagotrophs were operationally classified into 3 trophic levels (Rassoulzadegan \& Sheldon 1986, Rassoulzadegan et al. 1988, Wikner \& Hagström 1988, Kuuppo-Leinikki 1990, Sherr \& Sherr 1991) based on size and genus according to Table 3. SD of $\pm 20 \%$ for flagellate enumeration is normally obtained by using this technique (Andersson \& Rudehäll 1993). The sizes of 15 cells per taxonomic group and sample were measured. Biovolumes were calculated according to HELCOM (1988) guidelines, and biomass carbon calculated according to Verity et al. (1992):

$$
\log \mathrm{C}=-0.363+0.863(\log \mathrm{CV})
$$

For flagellates, the carbon biomass was ca. $25 \%$ of the wet weight.

Mesozooplankton. Mesozooplankton was sampled from the bottom to the surface with a vertical nethaul using a WP-2 net (mesh size $90 \mu \mathrm{m}$ ) (Tranter 1968). Samples were taken every 2 nd week between May and October and every 3rd week during winter. Samples were immediately preserved with 2 to $4 \%$ formaldehyde (di-sodium-tetraborate buffered, Dy-

Table 3. Grouping of phagotrophic flagellates into trophic levels at the sampling sites. For criteria used in grouping the flagellates, see 'Materials and methods'

\begin{tabular}{|c|c|c|c|}
\hline Trophic level & Bothnian Bay & Öre Estuary & Bothnian Sea \\
\hline Bactivorous & $\begin{array}{l}\text { Unidentified heterotrophic }^{\mathrm{a}} \\
\text { Unidentified mixotrophic }^{\mathrm{a}}\end{array}$ & $\begin{array}{l}\text { Unidentified heterotrophic }{ }^{a} \\
\text { Unidentified mixotrophic }^{a}\end{array}$ & $\begin{array}{l}\text { Unidentified heterotrophic }{ }^{\mathrm{a}} \\
\text { Unidentified mixotrophic }\end{array}$ \\
\hline Phagotrophic 2 & $\begin{array}{c}\text { Chrysochromulina spp. }{ }^{\mathrm{b}} \\
\text { Unidentified mixotrophic }^{\mathrm{a}, \mathrm{b}} \\
\text { Other }^{\mathrm{b}}\end{array}$ & $\begin{array}{c}\text { Chrysochromulina spp. }{ }^{\mathrm{a}, \mathrm{b}, \mathrm{c}} \\
\text { Unidentified mixotrophic } \\
\text { Other }{ }^{\mathrm{a}, \mathrm{b}}\end{array}$ & $\begin{array}{c}\text { Chrysochromulina spp. } .^{\mathrm{a}, \mathrm{b}, \mathrm{c}} \\
\text { Unidentified mixotrophic }^{\mathrm{b}} \\
\text { Other }^{\mathrm{b}}\end{array}$ \\
\hline Phagotrophic 3 & $\begin{array}{c}\text { Cryptophyceans } s^{\mathrm{b}, \mathrm{c}} \\
\text { Dinoflagellates }^{\mathrm{c}} \\
- \\
\text { Choanoflagellates }^{\mathrm{c}} \\
- \\
-\end{array}$ & $\begin{array}{l}\text { Cryptophyceans } \mathrm{s}^{\mathrm{b}, \mathrm{c}} \\
\text { Dinoflagellates }^{\mathrm{c}} \\
\text { Dinophysis sp. }^{\mathrm{c}} \\
\text { Choanoflagellates }^{\mathrm{c}} \\
\text { Dinobryon sp. } \\
\text { Eutreptiella sp. }\end{array}$ & $\begin{array}{l}\text { Cryptophyceans } \mathrm{s}^{\mathrm{b}, \mathrm{c}} \\
\text { Dinoflagellates }^{\mathrm{c}} \\
\text { Dinophysis sp. }^{\mathrm{c}} \\
\text { Choanoflagellates }^{\mathrm{c}} \\
\text { Dinobryon sp. }{ }^{\mathrm{c}} \\
\text { Eutreptiella sp. }{ }^{\mathrm{c}}\end{array}$ \\
\hline
\end{tabular}


bern et al. 1976). Sub-samples were analysed in an inverted microscope and at least 500 specimens counted from each sample. Species were identified as in Johansson (1992) and references therein. The length of the zooplankton was measured with calibrated microscopic scales at $100 \times$ magnification ( $\mathrm{n}=5$ to 10 ). The biomass was calculated by weight-length regressions according to Hernroth (1985) and Kankaala \& Johansson (1986). From these biomass estimates, mesozooplankton production was estimated from calculated biomass and equations for temperature-dependent growth rates, assuming steady-state conditions (Johansson 1992).

Fish. The herring biomass (dominant fish species in each area) was taken from the ICES Advisory Committee on Fishery Management (ACFM) report for the year 1991 (ICES 2001). It was assumed that carbon content was $10 \%$ of the wet weight of the fish biomass. It was further assumed that besides herring, an additional $20 \%$ of the total fish biomass constitutes other fishes according to the assumptions made by Elmgren (1984). On an areal basis it was assumed that the biomass was equal in ÖE and BS.

\section{RESULTS}

During 1991 the annual average temperature in the 0 to $20 \mathrm{~m}$ layer was slightly below $7^{\circ} \mathrm{C}$ both in $\mathrm{BB}$ and the coastal station ÖE (Table 2), and ca. $1^{\circ} \mathrm{C}$ higher in BS ( $p<0.05$, Wilcoxon's signed rank test). The maximum surface temperature at the offshore stations exceeded that at the coastal station. Subsurface minimum values never dropped below $1.0^{\circ} \mathrm{C}$ in $\mathrm{BS}$. A very mild ice winter caused a short period of ice coverage compared to the BB average and coastal areas of the Bothnian Sea. No continuous ice cover occurred in the central Bothnian Sea.

Salinity was $>2$ psu lower in BB than in BS over the whole water column, with intermediate salinity at ÖE. Due to the high freshwater input from the Öre River, salinity in ÖE was more variable.

As described in Andersson et al. (1996), light influx to the euphotic zone (0 to $20 \mathrm{~m}$ layer) was 5 -fold lower in BB than BS. The coastal station showed an intermediate value. All differences were statistically significant according to a Wilcoxon signed-rank test ( $\mathrm{p}<$ 0.015). The differences were mainly due to different light intensities during the ice-free season, rather than to differences in the period of ice coverage, and also as a consequence of lower incident light influx (i.e. $I_{0}$ value) rather than a higher attenuation coefficient (Beer's law, cited in Andersson et al. 1994). Maximum and minimum light influx values in BB were also clearly lower than at the other locations.

\section{Sedimentation}

The resuspension corrected-sedimentation rates measured by the traps were clearly different among the 3 areas. The total sedimentation was $10 \mathrm{mmol} \mathrm{C}$ $\mathrm{dm}^{-2} \mathrm{yr}^{-1}$ in $\mathrm{BB}$ (0 to $\left.30 \mathrm{~m}\right), 69 \mathrm{mmol} \mathrm{C} \mathrm{dm} \mathrm{mr}^{-2} \mathrm{yr}^{-1}$ in ÖE ( 0 to $14 \mathrm{~m}$ ) and $17 \mathrm{mmol} \mathrm{C} \mathrm{dm}{ }^{-2} \mathrm{yr}^{-1}$ in $\mathrm{BS}(0$ to $30 \mathrm{~m})$. Since these values do not correspond to the sedimentation of carbon in the whole water column $(41,16$ and $66 \mathrm{~m}$ in BB, ÖE and BS, respectively) used in the carbon budget (see 'Discussion'), additional utilisation of organic carbon below the sediment trap measurements had to be assumed from bacterial production data. A rough estimation suggests that bacteria may consume some $7 \mathrm{mmol} \mathrm{C} \mathrm{dm} \mathrm{mr}^{-2} \mathrm{yr}^{-1}$ of the sedimentation values (between 30 and $41 \mathrm{~m}$ ) in $\mathrm{BB}$, leaving $3 \mathrm{mmol} \mathrm{C} \mathrm{dm}{ }^{-2}$ $\mathrm{yr}^{-1}$ for export. Bacterial degradation was further estimated to be $19 \mathrm{mmol} \mathrm{C} \mathrm{dm}{ }^{-2} \mathrm{yr}^{-1}$ (102\%, between 30 and $66 \mathrm{~m}$ ) of the carbon settling from the euphotic zone in BS. Contribution from the 14 to $16 \mathrm{~m}$ layer in the ÖE to carbon degradation was assumed to be negligible.

\section{Phytoplankton}

Cells larger than $10 \mu \mathrm{m}$ (primarily diatoms and dinoflagellates) generally dominated the phytoplankton biomass at all stations, and constituted 63, 73 and $61 \%$ of the total annual average phytoplankton biomass in BB, ÖE and BS, respectively (Table 4). An exception was that unicellular cyanobacteria accounted for a large fraction of the total phytoplankton biomass in late summer at the offshore station in BS. Flagellated phytoplankton (2 to $10 \mu \mathrm{m}$ ) generally constituted a small proportion of the biomass $(12 \%$ of total biomass in BB and BS and $8 \%$ in ÖE), especially when compared to the estimated production in this size fraction. Cyanobacteria accounted for ca. $25 \%$ of the phytoplankton biomass in BB and BS, and ca. $20 \%$ in ÖE. Thus the proportions of the 3 size classes of phytoplankton were similar in all areas.

Phytoplankton succession showed a clear spring bloom in BS, with a peak of algae $>10 \mu \mathrm{m}$. Large algae also dominated the phytoplankton biomass during spring at the coastal station, while no clear spring bloom was observed in BB. Phytoplankton taxonomy and ecology are presented in greater detail in Andersson et al. (1996).

The total annual phytoplankton carbon fixation in BB was only $1 / 4$ of that in the open BS, with the coastal station in BS having intermediate values (Table 4). The $95 \%$ CIs of the annual estimate was calculated to average $\pm 8 \%(n=152)$ based on estimated SD, which suggested that these differences were statistically significant. 
Table 4. Average biomass carbon demand, annual production, respiration, excretion of dissolved organic carbon (DOC) (all mmol $\left.\mathrm{C} \mathrm{dm}{ }^{-2} \mathrm{yr}^{-1}\right)$, biomass $\left(\mathrm{mmol} \mathrm{C} \mathrm{dm}{ }^{-2}\right.$ ), and production to biomass ratio ( $\left.\mathrm{P}: \mathrm{B}\right)\left(\mathrm{yr}^{-1}\right)$ for the trophic components in the food web. Measured values are shown in bold, whereas modelled flows are shown as plain text (see 'Discussion' for details)

\begin{tabular}{|c|c|c|c|c|c|c|c|}
\hline Stn & Trophic component & $\begin{array}{l}\text { Carbon } \\
\text { demand }\end{array}$ & Production & Respiration & Excretion DOC & Biomass & $\mathrm{P}: \mathrm{B}$ \\
\hline \multirow[t]{18}{*}{ A13 (BB) } & Primary production & & & & & & \\
\hline & Pelagic carbon fixation & & & & & & \\
\hline & Algae $>10 \mu \mathrm{m}$ & & 4.7 & & & 0.80 & 5.9 \\
\hline & Algae $2-10 \mu \mathrm{m}$ & & 4.7 & & & 0.15 & 31 \\
\hline & Cyanobacteria unicell. & & 2.3 & & & 0.32 & 7.4 \\
\hline & Exudate & & 12 & & & & \\
\hline & Total autotrophic & & 23.7 & & & 1.3 & \\
\hline & Allochthonous organic matter & & 18 & & & 111 & \\
\hline & Secondary production & & & & & & \\
\hline & Virioplankton & 2.9 & 0.23 & 0.0 & 2.7 & 0.03 & 7.4 \\
\hline & Bacterioplankton & 58 & 17 & 40 & - & 0.57 & 31 \\
\hline & Bactivorous flagellates & 13 & 5.0 & 1.3 & 6.3 & 0.03 & 151 \\
\hline & Phagotrophic flagellates 2 & 6.6 & 2.7 & 0.7 & 3.3 & 0.04 & 73 \\
\hline & Phagotrophic flagellates 3 & 4.7 & 1.9 & 0.5 & 2.4 & 0.19 & 10 \\
\hline & Microzooplankton & 4.8 & 1.9 & 0.5 & 2.4 & - & - \\
\hline & Mesozooplankton & 5.9 & 1.5 & 1.5 & 3.0 & 0.04 & 41 \\
\hline & Fish & 1.5 & 0.22 & 1.0 & 0.3 & 0.09 & - \\
\hline & Total heterotrophic & 97 & 31 & 46 & 20 & 1.0 & \\
\hline \multirow[t]{18}{*}{ B3 (ÖE) } & Primary production & & & & & & \\
\hline & Pelagic carbon fixation & & & & & & \\
\hline & Algae $>10 \mu \mathrm{m}$ & & 10.2 & & & 1.02 & 10 \\
\hline & Algae $2-10 \mu \mathrm{m}$ & & 4.5 & & & 0.11 & 40 \\
\hline & Cyanobacteria unicell. & & 3.6 & & & 0.26 & 14 \\
\hline & Exudate & & 15.1 & & & & \\
\hline & Total autotrophic & & 33.3 & & & 1.4 & \\
\hline & Allochthonous organic matter & & 208 & & & 66 & \\
\hline & Secondary production & & & & & & \\
\hline & Virioplankton & 3.2 & 0.18 & 0.0 & 3.0 & 0.02 & 11 \\
\hline & Bacterioplankton & 45 & 13 & 31 & - & 0.24 & 56 \\
\hline & Bactivorous flagellates & 10 & 4.1 & 1.0 & 5.1 & 0.04 & 115 \\
\hline & Phagotrophic flagellates 2 & 5.8 & 2.3 & 0.6 & 2.9 & 0.04 & 52 \\
\hline & Phagotrophic flagellates 3 & 4.5 & 1.8 & 0.4 & 2.2 & 0.16 & 12 \\
\hline & Microzooplankton & 5.8 & 2.3 & 0.6 & 2.9 & - & - \\
\hline & Mesozooplankton & 8.9 & 2.2 & 2.2 & 4.4 & 0.08 & 26 \\
\hline & Fish & 2.2 & 0.3 & 1.4 & 0.4 & 0.44 & - \\
\hline & Total heterotrophic & 85 & 27 & 38 & 21 & 1.0 & \\
\hline \multirow[t]{18}{*}{ C1 (BS) } & Primary production & & & & & & \\
\hline & Pelagic carbon fixation & & & & & & \\
\hline & Algae $>10 \mu \mathrm{m}$ & & 22 & & & 2.04 & 11 \\
\hline & Algae $2-10 \mu \mathrm{m}$ & & 13 & & & 0.39 & 33 \\
\hline & Cyanobacteria unicell. & & 12 & & & 0.89 & 14 \\
\hline & Exudate & & 44 & & & & \\
\hline & Total autotrophic & & 91 & & & 3.33 & \\
\hline & Allochthonous organic matter & & 7.7 & & & 177 & \\
\hline & Secondary production & & & & & & \\
\hline & Virioplankton & 8 & 0.45 & 0.0 & 7.6 & 0.04 & 10 \\
\hline & Bacterioplankton & 112 & 34 & 78 & 0.0 & 0.82 & 41 \\
\hline & Bactivorous flagellates & 26 & 10 & 2.6 & 13 & 0.09 & 117 \\
\hline & Phagotrophic flagellates 2 & 16 & 6.3 & 1.6 & 7.9 & 0.16 & 81 \\
\hline & Phagotrophic flagellates 3 & 13 & 5.0 & 1.3 & 6.3 & 0.45 & 22 \\
\hline & Microzooplankton & 15 & 6.1 & 1.5 & 7.6 & - & - \\
\hline & Mesozooplankton & 21 & 5.3 & 5.3 & 10.7 & 0.07 & 77 \\
\hline & Fish & 5.3 & 0.8 & 3.5 & 1.1 & 0.44 & - \\
\hline & Total heterotrophic & 216 & 68 & 94 & 54 & 2.1 & \\
\hline
\end{tabular}


The productivity in each size class of phytoplankton differed more among areas than the biomass. Cyanobacterial production was similar in all areas, and ranged between 10 and $13 \%$ of total carbon fixation. Phytoplankton (2 to $10 \mu \mathrm{m}$ ) had the highest relative productivity in BB $(20 \%)$, but this was lower (13 to $14 \%$ ) in the other 2 areas (Table 4 ). The 2 to $10 \mu \mathrm{m}$ size fraction had the highest productivity:biomass (P:B) ratio at all sites (Table 4). Carbon fixation by phytoplankton $>10 \mu \mathrm{m}$ equalled that of the 2 to $10 \mu \mathrm{m}$ size class in BB $(20 \%)$, and dominated particulate productivity in ÖE (30\%) and BS (24\%, Table 4).

A pronounced spring bloom with high $\mathrm{CO}_{2}$ fixation (dominated by large algae) was only apparent at the offshore station in BS. On an annual basis, nearly half of the total phytoplankton carbon fixation resulted in DOC at all stations $(50,45$ and $48 \%$, respectively) (Table 4). This estimate includes ${ }^{14} \mathrm{C}$ in the bacterial size fraction $(0.2$ to $0.6 \mu \mathrm{m})$, assuming $50 \%$ bacterial assimilation efficiency of this substrate (within the range reported in del Giorgio \& Cole 1998). These values should be treated with some caution, as our own control experiments and communication with other investigators suggest that post-filtration occasionally gives rise to artefacts, especially in the smaller size fractions.

A strong correlation was observed between total carbon fixation and light influx to the euphotic zone, suggesting that the difference in light intensity between stations could explain $90 \%$ of the variability in phytoplankton carbon fixation $\left(\mathrm{r}^{2}=0.90, \mathrm{p}<0.001\right)$. The data not only represented the full seasonal cycle at all stations, but also data from parts of 1992 and 1993, when simultaneous measurements of light influx and carbon fixation were made.

\section{Bacteria}

The annual bacterial biomass was $0.57,0.24$ and $0.82 \mathrm{mmol} \mathrm{C} \mathrm{dm}{ }^{-2}$ in $\mathrm{BB}, \mathrm{Ö} E$ and $\mathrm{BS}$, respectively (Table 4). This was mainly a consequence of average depths, as volume-based concentrations were relatively similar among areas. ÖE had the highest volu-

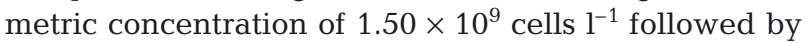

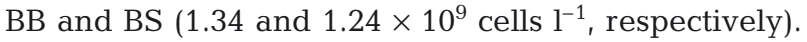
The bacterial biomass was comparatively high in relation to the total standing stock of phytoplankton in BB (approximately $44 \%$ of total phytoplankton biomass), but lower in the ÖE and BS (17 and $25 \%$, respectively). Among the heterotrophic organisms, bacteria had the largest biomass in the offshore areas (BB 48\%, BS $36 \%)$. Wikner \& Hagström (1999) provide a more detailed analysis of the intra-annual variability of bacterioplankton.
Annual integrated bacterioplankton carbon production was clearly highest in BS and lowest in ÖE, covarying with the average depth of the water column (Table 4). On a volumetric basis, growth rates in the surface water were clearly lower in BB than the other sites. Considering the uncertainty of the thymidine and biomass conversion factors, the bacterial production per volume at ÖE was not significantly lower (12\%) than at the offshore BS station. In the deep water, growth rates were, however, $50 \%$ higher in $\mathrm{BB}$ than BS. The $95 \%$ CI of the annual estimate was calculated as $\pm 4 \%(n=140)$. This was based on the sum of depth and time variance, assuming that a running 3-point average approximately reflected the true seasonal variability.

Bacterial carbon production amounted to ca. 74, 40 and $37 \%$ of the total phytoplankton carbon production in BB, ÖE and BS, respectively. Consequently, heterotrophic bacterial growth alone could consume most of the available autochthonous carbon production in $\mathrm{BB}$, suggesting allochthonous sources to be of particular importance in this basin.

\section{Protozooplankton}

The distribution of biomass among the 3 operationally defined size classes of protozooplankton was similar in all areas. The highest flagellate trophic level comprised mostly of the total phagotrophic flagellate biomass at all stations (Table 4). Bacterivorous flagellates had a similar biomass as Category 2 flagellates in BB and ÖE. In BS, however, bacterivorous flagellates comprised only half the Category 2 flagellates. The highest concentration of biomass was found at the coastal station for all categories (data not shown). The seasonal variations of the different phagotrophic flagellates were generally similar, with the differences being mainly in the magnitude of the biomass peaks (J. Wikner unpubl. data). For most genera, the dominating biomass was within a single defined size range (Table 3). However, Chrysochromulina spp. periodically covered all 3 size classes. Also, seasonal variation co-varied within each genus, irrespective of size class (data not shown). Therefore, each genus was assigned to a single functional group (e.g. trophic level), although we recognise that larger cells might prefer larger prey.

With the applied classification, the composition of the dominating bacterivorous flagellates and their primary predators was similar for all stations (Table 3). The number of genera in the group of largest flagellates was greater at BS stations than in BB. Three phago- or mixotrophic flagellate genera in the highest trophic level were abundant at all stations. 


\section{Mesozooplankton}

The mesozooplankton community was characterised by a few dominating species in each area. In terms of total biomass the zooplankton community in BB was about half of that found in ÖE and BS (Table 4). Rotatoria constituted the smallest share of the total zooplankton biomass in each area ( 2 to $4 \%$ ), and were dominated by Synchaeta spp. Cladoceran biomass was dominated by Bosmina longispina maritima in all areas, but its contribution to total zooplankton biomass was higher $(25 \%)$ in ÖE compared to BB and BS (8 to $9 \%$ ). Copepods clearly dominated the zooplankton community in all areas, being relatively more important in BB and BS (87 to 91\%) thanin ÖE (71\%). Limnocalanus macrurus dominated copepod biomass in BB, while Eurytemora affinis dominated in ÖE and BS. The biomass of Eurytemora affinis in BB and Acartia bifilosa in ÖE and BS constituted about half of the dominating zooplankton in the respective areas.

Integrated annual mesozooplankton growth rates, calculated from measured biomass and reported temperature dependent growth rates, showed higher values in BS than in BB. Total zooplankton production was found to be 1.7, 2.6 and $4.4 \mathrm{mmol} \mathrm{C} \mathrm{dm}{ }^{-2} \mathrm{yr}^{-1}$ in $\mathrm{BB}, \mathrm{ÖE}$ and $\mathrm{BS}$, respectively.

\section{DISCUSSION}

\section{Does TDOC input enhance bacterial biomass and production in the Gulf of Bothnia?}

The main objective of this study was to elucidate how riverine TDOC influences food web structure and processes in the Gulf of Bothnia. As outlined in the 'Introduction', we hypothesised that in areas with a high contribution of riverine organic carbon and a long residence time, TDOC would be an important source of carbon and energy for the pelagic food web. As a consequence, the alternate source of dissolved substrate provided by TDOC, would lead to an uncoupling of bacterio- and phytoplankton productivity. According to our hypothesis, the results for BB particularly corroborate previous studies, showing that high input of TDOC leads to an uncoupling of bacterial productivity and biomass from phytoplankton productivity (Findlay et al. 1991). A cross-ecosystem analysis of the ratio of bacterial to phytoplankton productivity in fresh and saltwater ecosystems suggested this ratio to be approximately $30 \%$ (Cole et al. 1988). In our study, it was markedly higher in BB (75\%) than found by Cole et al. (1988), but only slightly higher in ÖE (41\%) and BS $(37 \%)$. Likewise, the ratio of bacterial to phytoplankton biomass was higher in BB (44\%) than in ÖE
$(17 \%)$ and BS (24\%). The bacterial-to-phytoplankton productivity and biomass ratios strongly suggest that resources other than phytoplankton carbon must fuel bacterial carbon demand in these ecosystems. These relationships also hold on a longer time perspective, as long-term monitoring at ÖE (1987 to 2001) and BB and BS (1991 to 2001) confirms the uncoupling between bacterial and primary production (J. Wikner unpubl. monitoring data). This supports the hypothesis that input of TDOC causes these relationships, since it is unlikely that episodic internal releases from benthos or senescence from fish or other long-lived organisms would support such a high bacterial biomass and productivity.

Extensive utilisation of TDOC will have marked implications for the carbon and energy balance at the ecosystem level. Net ecosystem production (NEP) is defined by Howarth \& Michaels (2001) as the difference between NPP and the respiration of all heterotrophs in the ecosystem (equivalent to the difference between GPP and all respiration by both autotrophs and heterotrophs). A negative NEP would infer that alternative sources of carbon, besides primary production, are available to the heterotrophic community and thereby sustain higher respiration rates and net heterotrophy of the ecosystem. We assumed that the C-14 technique used in this study approximately measured NPP (Howarth \& Michaels 2001). Applying a net growth efficiency of $30 \%$ for bacteria, experimentally determined for the Gulf of Bothnia area (Zweifel et al. 1993), to the bacterial production rates presented (Table 4), would lead to an estimate of bacterial respiration alone to be $70 \%$ higher than the total primary production in BB. The corresponding value for ÖE and BS amounted to $90 \%$ of the primary production in both cases. Consequently, adding respiration from other secondary consumers, it is likely that NEP is negative at all stations, and that especially the BB ecosystem is clearly net heterotrophic. This suggested that sources of carbon other than that supplied from primary production were available to bacteria. The most likely explanation would be TDOC discharge, which, during the year of this study, constituted ca. 43,86 and $8 \%$ of the pelagic primary production in $\mathrm{BB}, \mathrm{OE}$ and $\mathrm{BS}$, and made up for the missing requirements fairly well.

The above reasoning relies on the reliability and validity to extrapolate the field data to the whole ecosystem. For instance, some sources of carbon may have been underestimated or overlooked, or bacterial respiration may have been overestimated. The bacterial thymidine conversion factor (TCF) and carbon density used per cell (average $15 \mathrm{fg} \mathrm{cell}^{-1}$ ) was in the lower range of factors reported (Bell 1993, Norland 1993). Using a lower factor of $1.0 \times 10^{18}$, instead of 
$1.5 \times 10^{18}$ cell $^{-1}$ mol thymidine ${ }^{-1}$ measured in the area by Wikner \& Hagström (1999), would still result in a net heterotrophic system in BB (data not shown). Also, using a similar TCF, the balance between bacterial productivity and mortality has been shown to match net change in bacterial abundance on an annual basis (Wikner \& Hagström 1991). Taken together, it was not likely that bacterial productivity was overestimated.

The estimated bacterial respiration is obviously quite sensitive to variations in the accuracy of the net growth-efficiency applied. For instance, the 30\% growth efficiency used here varies intra-annually between 11 and $54 \%$ (Zweifel et al. 1993). Using a growth efficiency of $40 \%$ decreases the total carbon demand to ca. $110 \%$ of the primary production in BB and $60 \%$ in the ÖE and BS areas. However, on a yearly basis it is probable that a true annual average value would approach $30 \%$, and we cannot satisfactorily explain the discrepancy in available carbon in the BB ecosystem with erroneous growth efficiency. The large fraction of humic compounds and low phosphorus content in the substrate pool of BB is expected to result in lower growth efficiency than used in this study. The consequence of this would be an even higher carbon demand, and thereby a larger discrepancy between demand and availability of carbon. Also, the applied growth efficiency was empirically determined and in good accordance with current values in the literature (delGiorgio \& Cole 1998). Monitoring data for BB, ÖE and BS shows that the annual bacterial carbon demand would probably be higher since the bacterial productivity to carbon fixation ratio was low in 1991 when compared to a 14 yr average (J. Wikner unpubl. monitoring data).

\section{Relative importance of TDOC for other food web components in the Gulf of Bothnia}

For other instances in the pelagic food web it was not possible to see any direct connections between food web structure and discharge of TDOC. Dominance relationships in terms of biomass between major functional groups were remarkably similar. Even though the biomass in the 3 size classes of phytoplankton differed among areas in absolute terms, each size class was proportionally similar. Organisms larger than $10 \mu \mathrm{m}$ (primarily diatoms and dinoflagellates) dominated the phytoplankton biomass at all stations (Table 4). Flagellated phytoplankton (2 to $10 \mu \mathrm{m}$ in size) generally accounted for a small proportion of the biomass, especially compared to the estimated production in this size fraction. Unicellular cyanobacteria constituted the second largest phytoplankton group (ca. $25 \%$ ).
The similar relative dominance of organisms in each size class in the 3 areas suggested that the controlling factors regulating biomass of major functional groups was comparable, irrespective of TDOC discharge and other differences between the basins. Among the heterotrophic organisms, the biomass patterns were also similar (Table 4). However, the relative share of small heterotrophs (less than zooplankton) of the total heterotrophic biomass (microzooplankton excluded) was ca. 87,49 and $75 \%$ in $\mathrm{BB}, \mathrm{O} \mathrm{E}$ and $\mathrm{BS}$, respectively. Thus, in BB and BS there seems to be a dominance of relatively small organisms in the heterotrophic community.

The lower total carbon fixation towards the north of the Gulf of Bothnia was most likely due to the lower light influx in this area, as suggested by Andersson et al. (1996). Total carbon fixation by phytoplankton was 4 -fold higher in BS than in BB (Table 4), with intermediate values in ÖE. For example, insolation differed significantly among areas (Wilcoxon signed rank-test) and was approximately 3 - and 5-fold lower in BB than in ÖE and BS, respectively (Table 2).

The measured size-fractionated primary production and estimated exudate production was proportionally similar in the 3 areas. The only difference was a slightly higher proportion of carbon fixation in the 2 to $10 \mu \mathrm{m}$ size fraction, and a lower proportion in the largest size fraction in $\mathrm{BB}$. The results suggest that most of the primary production in all areas would contribute to the food resources of smaller heterotrophic organisms. Exudates or phytoplankton less than $10 \mu \mathrm{m}$ comprised the major fraction of the total primary production (Table 4). As much as 50, 45 and $48 \%$ of the carbon fixation was lost through exudates, in BB, ÖE and BS. This must be considered rather high compared to an average of $13 \%$, compiled from several ecosystems (Baines \& Pace 1991). The stress of inorganic nutrient limitation as a result of competition with carbon- and energy-replete bacterioplankton could possibly promote a high exudation rate by phytoplankton (Joiris et al. 1982). Thus, no clear direct TDOC effect on the size distribution of phytoplankton carbon fixation could be demonstrated.

An indirect effect of high TDOC discharge on phytoplankton productivity, in addition to lower light influx, could be that as a consequence of the alternate carbon source of TDOC, bacteria might compete more intensively with phytoplankton for phosphorus in BB. Chemostat studies have also shown that bacteria may outcompete phytoplankton when provided with an alternate carbon source (Currie \& Kalff 1984). An alternate DOM resource for bacteria and the relatively high bacterial phosphorus ratio (C:N:P of 45:10:1, Zweifel et al. 1993) would partially explain the P limitation of primary production in the area (Andersson et al. 1996). 
For instance, by applying these ratios to the bulk phytoplankton and bacterial biomass in BB, ÖE and BS (Table 4), the ratio of the phosphorus bound in phytoplankton to that in bacteria would be about $0.9,2.4$, and 1.7 in BB, ÖE and BS respectively. Therefore a substantial amount of the total $\mathrm{P}$ pool could be bound into the $\mathrm{BB}$ bacterial community compared to the 2 other areas in the Gulf of Bothnia. Taken together both low light influx and competition between phytoplankton and bacteria for phosphorus would contribute to the low primary production in BB ecosystem. Furthermore, as shown by Zweifel et al. (1995) in seawater cultures during 1991-1992, the bacterial degradation of the DOC pool is partly limited by the availability of phosphorus and nitrogen.

\section{Relative importance of TDOC to the overall carbon budget in the Gulf of Bothnia}

Most of the reasoning so far is based on the indirect importance of TDOC based on empirical results from pelagic biological measurements and also from estimations of bacterial respiration. However, since TDOC has been regarded as recalcitrant and not biodegradable to the food web, alternative sources of carbon and its pathways need to be addressed. Here we present a tentative picture of how carbon flows through the food webs in the Gulf of Bothnia, since models on carbon flow budgets of the pelagic zone are presently not available. The model (Fig. 2) serves 3 purposes: (1) to present likely pathways of carbon from the bottom of the food web, e.g. pelagic primary producers and TDOC, to higher trophic levels; (2) to quantitatively estimate the relative importance of TDOC in the supply of DOC to bacteria; and (3) to calculate ecosystem carbon balance from inputs of carbon via TDOC, pelagic and benthic primary production, with carbon losses via total heterotrophic respiration. In Fig. 2, solid arrows indicate the carbon flows based on real measurements made during 1991 in the Gulf of Bothnia, whereas dotted arrows represent modelled flows. Points (1) to (3) also represent 3 different scales at which carbon flows were presented and evaluated. In the following calculations, we do not claim to present a true picture of carbon flow, but rather a tentative or heuristic model of the pelagic food web and the relative importance of TDOC. We consider this exercise to give valuable new information on the impact of TDOC on estuarine waters by the synthesis of a carbon budget from earlier reports (Zweifel et al. 1995, Andersson et al. 1996, Wikner \& Hagström 1999) and by including simultaneous estimates of TDOC discharge. The unique dataset of contemporary measurements of many variables and 3 sampling sites over a full annual cycle also provide annual estimates not previously available.

\section{Estimations of pelagic carbon flow}

Carbon flow in pelagic food webs in the Gulf of Bothnia was modelled by simple mass-balance constraints. For instance, for any predator (j) its carbon demand $Q_{\mathrm{j}}$ can be divided into:

$$
Q_{\mathrm{j}}=P_{\mathrm{j}}+R_{\mathrm{j}}+E_{\mathrm{j}}
$$

where $P_{\mathrm{j}}$ is biomass productivity, $R_{\mathrm{j}}$ respiration and $E_{\mathrm{j}}$ the part of consumption not assimilated. Since no productivity measurements were made on heterotrophs other than bacteria and zooplankton, the productivity of flagellates and microzooplankton must be estimated
Fig. 2. Model showing the principal structure of the food webs and organism groups. Arrows indicate fluxes with different type for estimated and calculated values. The shaded ellipse represents microheterotrophic organisms. The brackets inside the ellipse refer to the carbon flow to/from all the microheterotrophs except viruses. Dotted flows from the ellipse as well as from mesozooplankton and fish represent flows to detritus (egestion + other potential sources) and respiration. DOM: dissolved organic matter; TDOM: total dissolved organic matter

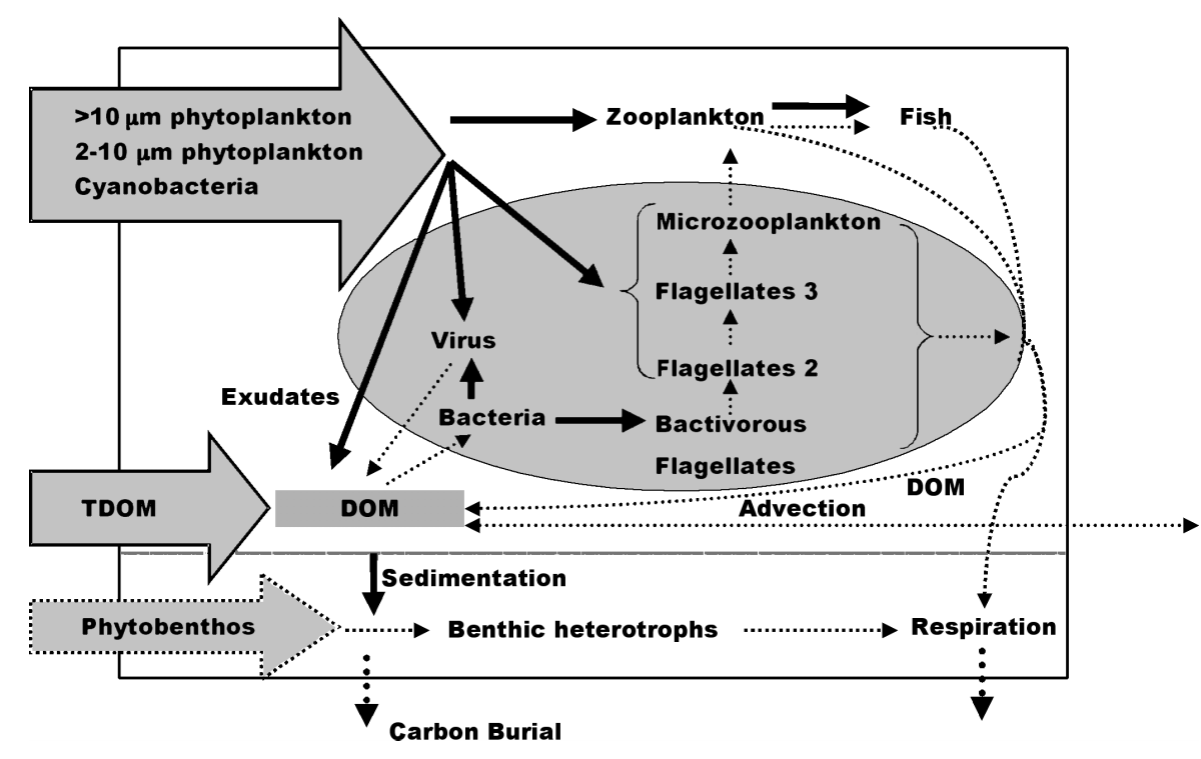


indirectly. It was assumed that for each predator $\mathrm{j}$, its biomass productivity $\left(P_{\mathrm{j}}\right)$ could be calculated according to:

$$
P_{\mathrm{j}}=Q_{\mathrm{j}} \times \mathrm{GE}_{\mathrm{j}}
$$

where $\mathrm{GE}_{\mathrm{j}}$ is the percentage of predator carbon demand allocated to biomass growth. For bacteria, GE is equivalent to net growth efficiency or the fraction of total assimilation allocated to growth, whereas for most other heterotrophs GE is equivalent to gross growth efficiency or the fraction of total ingestion allocated to growth. In the model, bacteria were assumed to have a $30 \%$ GE, experimentally determined by Zweifel et al. (1993). For all flagellates and microzooplankton we assumed a somewhat higher GE of $40 \%$, whereas zooplankton was assumed to have a GE of $25 \%$. For flagellates and microzooplankton, the GE used here is ca. $10 \%$ higher than typical rates in nature (Straile 1997). We justify this discrepancy by assuming that flagellates and microzooplankton are favoured by high bacterial productivity in these areas.

It was further assumed that $Q_{\mathrm{j}}$ could be calculated from:

$$
Q_{j}=\sum_{i=1}^{n} \mathrm{DC}_{\mathrm{ji}} \times P_{\mathrm{i}}
$$

$\mathrm{DC}_{\mathrm{ji}}$ represents the fraction of prey $\mathrm{i}$ productivity $\left(P_{\mathrm{i}}\right)$ allocated to predator j. Relevant assumptions on $\mathrm{DC}_{\mathrm{ji}}$ for each predator are available in Table 5 . Mesozooplankton productivity was calculated according to this procedure and compared with the alternative productivity estimations made in the methods section.

Table 5. Rows represent partitioning (\%) of resources to a certain consumer (A-H). Columns show partitioning of a consumers total carbon demand from different resources. Resource partitioning values, based on measurements in the annual field study, are shown in bold. Values derived from previous studies in the Baltic are shown in normal font. Predator preference for a certain prey (\%) was in general based on literature values (see notes below the table). Resource partitioning values based on reports from

\begin{tabular}{|c|c|c|c|c|c|c|c|c|c|}
\hline \multirow[t]{2}{*}{ Resource (prey) } & \multicolumn{9}{|c|}{ Consumer (predator) (\% resource production) } \\
\hline & $\mathrm{A}^{\mathrm{a}}$ & $\mathrm{B}^{\mathrm{b}}$ & $\mathrm{C}^{\mathrm{c}}$ & $\mathrm{D}^{\mathrm{d}}$ & $\mathrm{E}^{\mathrm{e}}$ & $\mathrm{F}^{\mathrm{f}}$ & $\mathrm{G}^{\mathrm{g}}$ & $\mathrm{H}^{\mathrm{h}}$ & Sum \\
\hline A. Virus & - & 0 & 0 & 0 & 0 & 0 & 0 & 0 & 0 \\
\hline Phyto- and zooplankton exudates & - & 100 & 0 & 0 & 0 & 0 & 0 & 0 & 100 \\
\hline \multirow{2}{*}{ B. Chemotrophic bacteria } & 10 & 0 & 70 & 20 & 0 & 0 & 0 & 0 & 100 \\
\hline & 10 & - & 20 & 30 & 20 & 20 & 0 & 0 & 100 \\
\hline \multicolumn{2}{|l|}{ C. Bactivorous flagellates } & - & - & 40 & 30 & 20 & 0 & 0 & $90^{\mathrm{i}}$ \\
\hline Phytoplankton 2-10 $\mu \mathrm{m}$ & 10 & - & - & 10 & 30 & 30 & 10 & 0 & $90^{\mathrm{i}}$ \\
\hline \multicolumn{2}{|l|}{ D. Phagotrophic flagellates $2^{\mathrm{j}}$} & - & - & - & 50 & 30 & 10 & 0 & $90^{\mathrm{i}}$ \\
\hline Phytoplankton $>10 \mu \mathrm{m}$ & 10 & - & - & - & - & 20 & 50 & 0 & $80^{\mathrm{i}}$ \\
\hline E. Phagotrophic flagellates $3^{j}$ & - & - & - & - & - & 10 & 70 & 0 & $80^{\mathrm{i}}$ \\
\hline F. Microzooplankton & - & - & - & - & - & - & 80 & 0 & $80^{\mathrm{i}}$ \\
\hline G. Mesozooplankton & - & - & - & - & - & - & - & 100 & 100 \\
\hline H. Fish and mysids ${ }^{\mathrm{k}}$ & - & - & - & - & - & - & - & - & 100 \\
\hline \multicolumn{5}{|c|}{$\begin{array}{l}10 \% \text { bacterial mortality agrees with Tuomi \& Kuuppo (1999) on the Gulf of Finland. This level also matches a previous mor- } \\
\text { tality estimate of bacterioplankton caused by protozooplankton in the Bothnian Sea area (Wikner \& Hagström 1991) }\end{array}$} & & & & & \\
\hline \multicolumn{10}{|c|}{${ }^{\mathrm{b}}$ Bacterial diet was assumed to be DOC } \\
\hline \multicolumn{10}{|c|}{$\begin{array}{l}\text { 'Wikner \& Hagström }(1988,1991) \text { have estimated that } 90 \% \text { of the carbon demand by bactivorous flagellates }(1-5 \mu \mathrm{m}) \text { consist } \\
\text { of picoplankton (similarly: Kuuppo-Leinikki 1990, Sherr \& Sherr 1991). It was assumed that } 70 \% \text { of this constituted bacteria } \\
\text { and } 20 \% \text { cyanobacteria (Hagström et al. 1988) }\end{array}$} \\
\hline \multicolumn{10}{|c|}{$\begin{array}{l}\text { dPrey size spectrum based on results from Rassoulzadegan \& Sheldon (1986), Wikner \& Hagström (1988), Sherr \& Sherr (1991) } \\
\text { and Dolan \& Gallegos (1991) }\end{array}$} \\
\hline \multicolumn{10}{|c|}{$\begin{array}{l}\text { ePrey size spectrum based on results from Rassoulzadegan \& Sheldon (1986), Wikner \& Hagström (1988), Sherr \& Sherr (1991) } \\
\text { and Dolan \& Gellegos (1991) }\end{array}$} \\
\hline \multicolumn{10}{|c|}{$\begin{array}{l}\text { fPrey size spectrum based on results from Fenchel (1980), Jonsson (1986), Rassoulzadegan et al. (1988), Verity \& Villareal } \\
\text { (1986) and Dolan \& Gellegos (1991). These prey size spectra agree with findings in the Gulf of Finland (Kivi et al. 1996), } \\
\text { where ciliates have strong regulating effects on prey }<10 \mu \mathrm{m} \text { in presence of zooplankton }\end{array}$} \\
\hline \multicolumn{10}{|c|}{$\begin{array}{l}\text { IFollowing Kivi et al. (1996), besides large phytoplankton }>10 \mu \mathrm{m} \text {, microzooplankton (e.g. ciliates) production is an important } \\
\text { part of zooplankton diets. For simplicity, it was assumed that despite the differences between areas in terms of biomass dom- } \\
\text { inance of different zooplankton, the total predation effect was similar on prey }>10 \mu \mathrm{m}\end{array}$} \\
\hline \multicolumn{10}{|c|}{ hTotal zooplankton production over the year was assumed to be consumed by planktivorous fish and mysids } \\
\hline \multicolumn{10}{|c|}{ iRemaining fraction exported by sedimentation according to field estimates } \\
\hline \multicolumn{10}{|c|}{ Phagotrophic flagellate groups 2 and 3 defined in Table 3} \\
\hline${ }^{\mathrm{k}}$ Carbon demand not satisfied through & & & & & & & & & \\
\hline
\end{tabular}
other environments, or rough estimates, are shown in italic 
Respiration $(R)$ of assimilated carbon and egestion $(E)$ of ingested carbon by heterotrophs are important variables to quantify, since total heterotrophic respiration can be used to calculate the NEP of an ecosystem and recycled carbon can be an important source of energy for bacterial DOC demand. $E_{\mathrm{j}}$ can be calculated from:

$$
E_{\mathrm{j}}=Q_{\mathrm{j}} \times \mathrm{AE}_{\mathrm{j}}
$$

where $A E_{j}$ is the fraction of total $Q_{\mathrm{j}}$ not assimilated.

We arbitrarily assumed a general assimilation efficiency of $50 \%$ for all protozoans and crustacean organisms. This might be low for some organisms, but we assume that the $E_{\mathrm{j}}$ besides egestion also includes breakdown of prey to DOC via sloppy feeding. Fish were arbitrarily assumed to have an assimilation efficiency of $80 \%$.

Based on the above assumptions, the modelled carbon flows for the pelagic community are shown as normal font in Table 4. This tentative model suggests that planktonic organisms that were less than $100 \mu \mathrm{m}$ in size accounted for approximately $80 \%$ of the carbon demand in the plankton community in these brackish water environments. Bacteria were responsible for 60 , 53 and $52 \%$ of the total carbon demand in BB, ÖE and $\mathrm{BS}$. In BB, bacterivorous flagellates accounted for an additional $13 \%$ of the total carbon demand, whereas the carbon demands of mesozooplankton and fish accounted for only $7.6 \%$. In ÖE and BS, mesozooplankton and fish accounted for approximately $13 \%$ of the total carbon demand. In our calculation, the carbon demands for organisms other than bacteria will, by definition, always balance since available prey resources, according to Table 5, set the carbon demands.

Any imbalance found between availability and required carbon would thus be due to bacterial carbon demands in each area, since bacterial carbon demand is calculated from measured productivity and literature values of the net growth efficiency of bacteria. As a consequence, the carbon demand of other heterotrophs in the model will never exceed prey productivity. This means that the magnitude of productivity of bacteria, as well as the 3 size classes of phytoplankton, directly influenced the magnitude of estimated total carbon demands, and they accordingly constitute a minimum estimate.

The estimate of bacterial productivity was shown to have the greatest impact on the budget results. A simple analysis of the sensitivity of total carbon demands to variations in productivity of bacteria and the 3 size classes of phytoplankton suggested that a given change in bacterial productivity accounted for approximately $85 \%$ of the change in total carbon demand. Likewise, the same change in particulate productivity of all the phytoplankton together accounts only for approximately $15 \%$. For example, $\pm 50 \%$ deviations in bacterial productivity correspond to a $43 \%$ change in total carbon demand. The corresponding change in all the 3 size classes of phytoplankton $( \pm 50 \%$ ) leads to a $7 \%$ change in total carbon demand, with only minor variations between BB, ÖE and BS.

The only indirect control of the accuracy of these estimates were the growth estimates of zooplankton from biomass measurements and temperature. Total zooplankton production was found to be 1.7, 2.6 and $4.4 \mathrm{mmol} \mathrm{C} \mathrm{dm}^{-2} \mathrm{yr}^{-1}$ in BB, ÖE and BS, whereas the corresponding modelled productivity was 1.5, 2.2 and $5.3 \mathrm{mmol} \mathrm{C} \mathrm{dm}{ }^{-2} \mathrm{yr}^{-1}$, respectively (Table 4). Accordingly, the flow of carbon through the food web from phytoplankton and bacteria did not seem to be unrealistic. The applied diets (Table 5), growth and assimilation efficiencies thus seemed to result in reasonable losses in each trophic link from the base of the food web before reaching the zooplankton compartment.

\section{Estimations of the relative importance of TDOC in bacterial DOC demand}

The DOC pool in aquatic systems can be supplied via phytoplankton exudates, TDOC, sloppy feeding, heterotrophic excretion and advection from adjacent ecosystems (see Fig. 2). Exudate production is available from this study, and sloppy feeding was assumed to be part of the estimated excretion. Details of the TDOC supply for BB and BS are available in Pettersson et al. (1997), which were used to estimate the areaspecific river input of organic carbon (24 Swedish and Finnish rivers). The input of TDOC to ÖE was estimated from the monitoring program of Swedish rivers (Department of Environmental Assessment, Swedish University of Agricultural Science, available at www. ma.slu.se/) during 1991 and the export of carbon from ÖE was assumed to be $90 \%$ of the TDOC input (Forsgren \& Jansson 1992). The advective carbon flow between the Bothnian Bay (BB) and the Bothnian Sea (BS) was estimated by assuming that the export of carbon from each basin was proportional to the basin DOC concentration. These values were multiplied by the advective flow of water between $\mathrm{BB}, \mathrm{BS}$ and the Baltic Proper (BP) basins (Wulff et al. 1994). DOC concentrations for the BB and BS basins were taken from this study, while an annual average of $0.31 \mathrm{mmol} \mathrm{C}$ $\mathrm{dm}^{-3}$ (Stn BY31, 1998) was assumed for the northern BP (U. Larsson 1999 pers. comm.). These estimates were calculated on a $\mathrm{dm}^{2}$ basis and for a water column corresponding to the average depth of each area (Table 1).

A compilation of all the sources of DOC available to bacteria in the pelagic zone and other losses (e.g. 

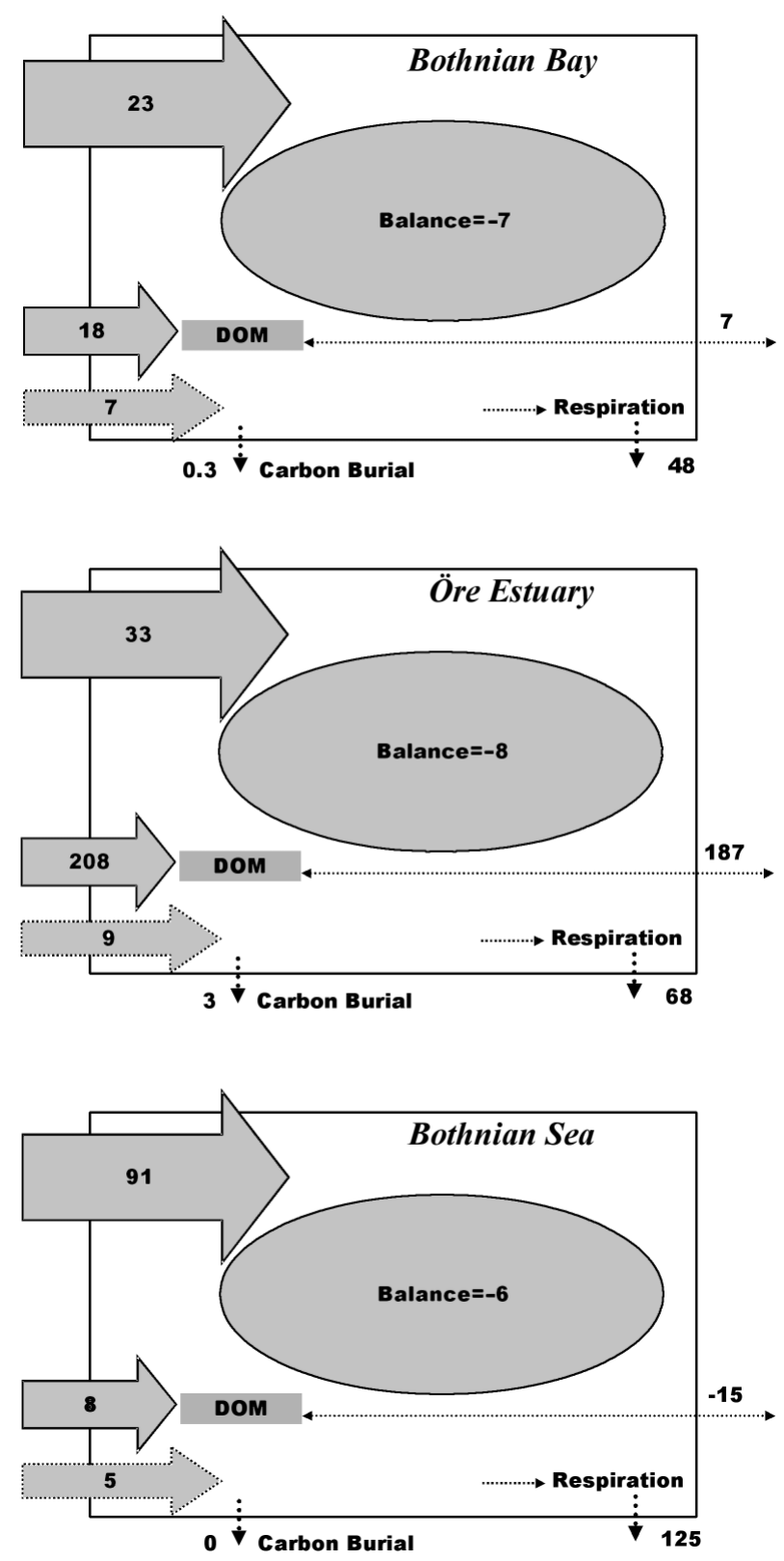

Fig. 3. Ecosystem carbon budget, showing the balance between total input and output of organic carbon in Bothnian Bay, Öre Estuary and the Bothnian Sea. Model structure and arrows correspond to the outer compartment in Fig. 2. All values are given in $\mathrm{mmol} \mathrm{C} \mathrm{dm}{ }^{-2} \mathrm{yr}^{-1}$

advection in $\mathrm{BB}$ ) are presented for each area in Fig. 3. The result shows a lack of some $12 \mathrm{mmol} \mathrm{C} \mathrm{dm}^{-2}$ of input in the DOC budget of $\mathrm{BB}$, while in ÖE there was a surplus of some $16 \mathrm{mmol} \mathrm{C} \mathrm{dm} \mathrm{mr}^{-2} \mathrm{yr}^{-1}$. In BS, the DOM surplus was ca. $17 \mathrm{mmol} \mathrm{C} \mathrm{dm}^{-2} \mathrm{yr}^{-1}$. Given the uncertainties involved in these calculations, it would probably have been possible to tune the utilised growth efficiencies and assimilation efficiencies so as to bring inputs and demands of carbon to an approximate steady state in the 2 open sea systems. However, we chose not to do so, since we do not really know whether the discrepancies are primarily due to underestimations of carbon inputs or to errors in the estimates of organism carbon demand and respiration. These results suggest that essentially all of the annual TDOC supply needs to be bioavailable in order to explain the estimated bacterial carbon demand.

\section{Estimations of ecosystem carbon balance}

A similar calculation can be made at the ecosystem level. The ecosystem carbon flows (outer frame Fig. 2), e.g. TDOC input and advection, have been described above. Indigenous primary production was calculated from the measurements of ${ }^{14} \mathrm{CO}_{3}{ }^{2-}$ uptake. Total phytobenthic production (including macrophytes, annual filamentous algae and microphytes) was assumed to be proportional to coastal primary production, as given in Kautsky (1995). In his estimation, phytobenthic production amounted to ca. $80 \%$ of the pelagic primary production in coastal areas at depths between 0 and $25 \mathrm{~m}$ (Swedish coastline) in BB, and 29\% in BS. From these crude relationships, phytobenthic primary production was estimated on the basis that these areas (0 to $25 \mathrm{~m}$ ) constitute ca. $40 \%$ of the total basin area in Bothnian Bay, and ca. $9 \%$ in Bothnian Sea (calculated from a hypsographic database, available at http:// data.ecology.su.se/Models/bed.htm). Despite the crudeness of these estimates, they are included as an illustration of the potential importance of phytobenthic carbon for basin-wide carbon flows. Estimations of pelagic heterotrophic respiration have been described above, while benthic macrofauna and meiofauna was taken from Elmgren (1984). Following estimations in Mohammadi et al. (1993), benthic bacterial respiration was assumed to be $20 \%$ of total benthic respiration. The amount of carbon sequestered in the sediments was estimated to be ca. $9 \%$ of the sedimentation supply in BB and $5 \%$ of the supply in BS (Elmgren 1984). These assumptions and the measured sedimentation rate were applied to estimate sequestered carbon in the sediments in each area (ÖE was assumed to sequester carbon in the same proportion as BS). All data were integrated over the average depth of each area (Table 1).

The ecosystem carbon budget (outer frame Fig. 2) showed that the net carbon input was estimated to be 48 (BB), 250 (ÖE) and 119 (BS) mmol C dm $\mathrm{Cr}^{-1}$, respectively (Fig. 4). The contribution of TDOC from rivers constituted 37,83 and $7 \%$ of the total carbon input in BB, ÖE and BS, respectively. ÖE showed a marked net output advection ( $75 \%$ of total input), 
DOM Carbon Budgets
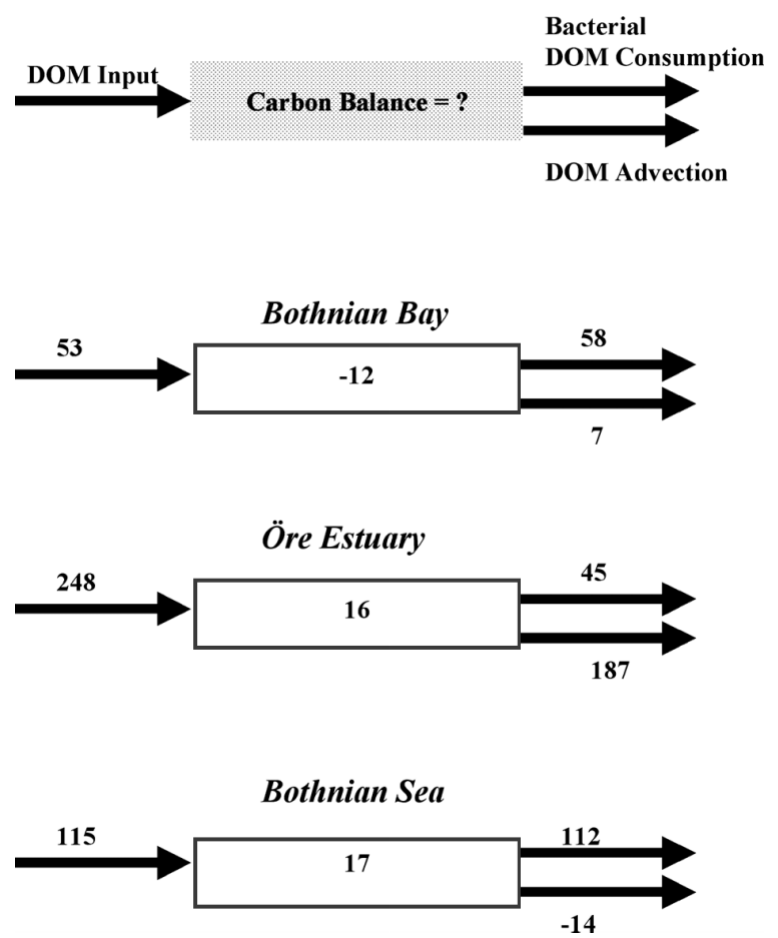

Fig. 4. Dissolved organic matter (DOM) carbon budget (see DOM compartment Fig. 2) in Bothnian Bay, Öre Estuary and the Bothnian Sea. The carbon balance in the pelagic zone is calculated from total DOM inputs and outputs. All values are given in mmol C dm-2 $\mathrm{yr}^{-1}$

while the corresponding value in $\mathrm{BB}$ was smaller (15\%, Fig. 4). BS, on the other hand, showed a net input. The resulting carbon availability within each system was therefore 41, 63 and $119 \mathrm{mmol} \mathrm{C} \mathrm{dm}^{-2} \mathrm{yr}^{-1}$ in $\mathrm{BB}, \mathrm{ÖE}$ and BS, respectively.

Total carbon losses through heterotrophic respiration, sequestration of carbon in sediments and advection (only $\mathrm{BB}$ and ÖE) in each system were, on the other hand, 55, 258 and $125 \mathrm{mmol} \mathrm{C} \mathrm{dm}^{-2} \mathrm{yr}^{-1}$ (Fig. 4). Thus, the calculated total carbon loss exceeded total carbon availability by some 7, 8 and $6 \mathrm{mmol} \mathrm{C} \mathrm{dm}{ }^{-2} \mathrm{yr}^{-1}$ in $\mathrm{BB}$, ÖE and $\mathrm{BS}$, respectively. Bacterial respiration accounted for almost all of the carbon loss $(40 \mathrm{mmol} \mathrm{C}$ $\mathrm{dm}^{-2} \mathrm{yr}^{1}$ ) in BB. Bacterial respiration in ÖE and BS

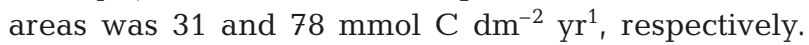
This corresponded to 84,45 and $61 \%$ of total respiration in BB, ÖE and BS, respectively. The total respiration for all other pelagic heterotrophs was ca. 4, 6 and $19 \mathrm{mmol} \mathrm{C} \mathrm{dm}^{-2} \mathrm{yr}^{-1}$ in BB, ÖE and BS, respectively. Based on a very rough estimate, benthic respiration was $6 \%$ in $\mathrm{BB}$, but corresponded to ca. 45 and $24 \%$ of the total heterotrophic respiration (Fig. 4) in ÖE and BS.

These results indicate that total carbon availability and carbon losses were approximately balanced in these ecosystems, even though there was a slight nominal deficiency in carbon availability (Fig. 4). Consequently, the carbon budget suggested that TDOC must be included in the ecosystem carbon budget as an important source of carbon for the brackish water ecosystem.

The balance found in BS in our study contradicts the clear net heterotrophy suggested by Zweifel et al. (1995). They compared bacterial carbon demand, rather than respiration alone, with autochthonous carbon fixation, which typically results in an overestimate of the heterotrophic processes (cf. Strayer 1988). Furthermore, the fact that we included the retention of the system (i.e. metabolism of sedimenting matter), and used a bacterial carbon content based on measured biovolume, amounting to half of that used by Zweifel et al. (1995), may explain the different budget results obtained.

Among other potential carbon resources, besides TDOC, neither carbon fixation by chemoautotrophic processes nor POM and DOM supply by precipitation were taken into account in our compilation, and could add to the DOM input. Estimates of annual average inputs of carbon through autochthonous primary production (TDOC and advection), expressed as mmol $\mathrm{C} \mathrm{dm}{ }^{-2}$, will obviously be uncertain. The source of errors in primary production measurements may arise from a lack of spatial coverage in favour of high temporal resolution. Bathymetric effects, such as the actual volume of water in which primary production occurs, in relation to the volume in which bacterial production occurs, may influence our understanding of the input/carbon demand balance in the Gulf of Bothnia. Further, the input of carbon via resuspension could be another important carbon supply to the pelagic food web. This could be especially important in ÖE due to the shallowness of the water column, as suggested by Zweifel et al. (1995), but would probably be of less importance at the offshore stations. Our sedimentation rate estimates were, however, corrected for resuspension, so this could therefore not be an additional source of carbon, as opposed to Zweifel et al. (1995).

Despite remaining uncertainties, we consider the food-web structure presented, based on new contemporary measurements with good annual coverage and integrated river discharge estimates, to provide a clearly more realistic picture of the carbon flows in the northern Baltic than previously available. In addition, the modelled zooplankton productivity correlated well with calculations from biomass estimates and growth functions from culture studies. This suggested that the modelled carbon flows and growth efficiencies we used were plausible. Furthermore, in this study the inclusion of 3 trophic links (flagellates) between bacte- 
ria and microzooplankton as well as viral infections have, in line with the suggestions made by Sandberg et al. (2000), improved the overall carbon budget considerably compared to those presented by Elmgren (1984).

The results of the whole-year field study of 3 different brackish water environments suggested that TDOC constituted an important carbon and energy resource, and the supply was an important part of the total input. This supported conclusions from earlier studies suggesting that the TDOC input must be an additional energy source enhancing zooplankton productivity in the Bothnian Bay (Ackefors et al. 1978, Rolff \& Elmgren 2000). High TDOC discharge consequently created net heterotrophy in the ecosystem, in accordance with conclusions from oxygen balance estimates at the water-air interface (Stigebrandt 1991). The carbon budget suggested that bacteria dominated total carbon consumption and respiration in each area. This was most clearly observed in the basin that had a high TDOC input and long residence time (BB). Our results further suggested that essentially all of the input of TDOC carbon to BB was metabolised in the food web, rather than exported out of the basin. This advocates a revision of the view that humus-rich TDOC is mainly a refractory resource (e.g. Elmgren 1984). Our results also lend support to recent studies suggesting that humic compounds, especially when discharged into waters of higher salinity, constitute an important nutrient and energy source for bacterioplankton (Stepanauskas et al. 1999, Wikner et al. 1999).

In brackish water environments, freshwater input affects several hydrographic and chemical factors, salinity being one of the most cited. The species composition of bivalves, macrophytes, large phytoplankton and protozoa in brackish water environments is mainly thought to be a consequence of the lower salinity (Elmgren 1984). Other differences, like the balance between heterotrophic and autotrophic production, and biomass of organism groups, are more likely explained by differences in the TDOC supply. We can also not exclude the fact that the occurrence or lack of some species was associated with the enhanced influence of terrigenous matter. Our study therefore suggested that TDOC, in addition to salinity, should be considered as a driving force for structural, functional and biogeochemical characteristics of brackish water environments.

Acknowledgements. We are grateful for the efforts and analyses made during the year-round sampling by the staff at Umeå Marine Science Centre and the Swedish Coast Guard Vessel KBV004. The authors would like to thank Dr. Anders Wilander, Dept. of Environmental Assessments,
SLU, Uppsala, for providing the data on terrigenous dissolved organic carbon, and Dr. Lars Rahm, Dept. of Water and Environmental Studies, Linköping University, for providing the data on water flows between the basins in the Gulf of Bothnia. Dr. Erik Lundberg (Umeå Marine Science Centre) is acknowledged for the analysis of DOC. Further, A. Wilander, R. Elmgren and F. Wulff made valuable comments and suggestions on earlier versions of the manuscript. This study was initiated by Dr. Åke Hagström as part of the 'Gulf of Bothnia year 1991', a joint Swedish-Finnish project by an initiative of the Committee for the Gulf of Bothnia. Financial support was provided from the Swedish Environmental Protection Agency (Dnr. 802-831-91-Fh, 802586-90-Fh).

\section{LITERATURE CITED}

Ackefors H, Hernroth L, Lindahl O, Wulff F (1978) Ecological production studies of the phytoplankton and zooplankton in the Gulf of Bothnia. Finn Mar Res 244:116-126

Andersson A, Rudehäll A (1993) Proportion of plankton biomass in particulate organic carbon in the northern Baltic Sea. Mar Ecol Prog Ser 95:133-139

Andersson A, Haecky P, Hagström A (1994) Effect of temperature and light on the growth of micro-, nano- and picoplankton: impact on algal succession. Mar Biol 120: 511-520

Andersson A, Hajdu S, Haecky P, Kuparinen J, Wikner J (1996) Succession and growth limitation of phytoplankton in the Gulf of Bothnia (Baltic Sea). Mar Biol 126:791-801

Baines S, Pace ML (1991) The production of dissolved organic matter by phytoplankton and its importance to bacteria: patterns across marine and freshwater systems. Limnol Oceanogr 36:1078-1090

Bell RI (1993) Estimating production of heterotrophic bacterioplankton via incorporation of tritiated thymidine. In: Kemp PF, Sherr BF, Sherr EB, Cole JJ (eds) Handbook of methods in aquatic microbial ecology. Lewis Publishers, Boca Raton, FL, p 495-503

Blomqvist S, Larsson U (1994) Detrital bedrock elements as tracers of settling resuspended particulate matter in a coastal area of the Baltic Sea. Limnol Oceanogr 39: 880-896

Burman JO (1987) Applications: geological. In: Boumans PWJM (ed) Inductively coupled plasma emission spectroscopy, Part 2. In: Elving PJ, Winefordner JD, Kolthoff IM (series eds) Analytical chemistry. Vol 90. John Wiley \& Sons, New York, p 27-47

Carlsson P, Granéli E (1993) Availability of humic bound nitrogen for coastal plankton. Estuar Coastal Shelf Sci 36: 433-447

Cochlan WP, Wikner J, Steward GF, Smith DC, Azam F (1993) Spatial distribution of viruses, bacteria and chlorophyll a in neritic, oceanic and estuarine environments. Mar Ecol Prog Ser 92:77-87

Cole JJ, Findlay S, Pace ML (1988) Bacterial production in fresh and saltwater ecosystems: a cross-system overview. Mar Ecol Prog Ser 43:1-10

Currie DJ, Kalff J (1984) Can bacteria outcompete phytoplankton for phosphorus? A chemostat test. Microb Ecol 10:205-216

delGiorgio PA, Cole JJ (1998) Bacterial growth efficiency in natural aquatic systems. Annu Rev Ecol Syst 29:503-541

delGiorgio PA, Cole JJ, Cimbleris A (1997) Respiration rates in bacteria exceed phytoplankton production in unproductive aquatic systems. Nature 385:148-151 
Dolan JR, Gallegos CL (1991) Trophic coupling of rotifers, microflagellates, and bacteria during fall months in the Rhode River Estuary. Mar Ecol Prog Ser 77:147-156

Duarte CM, Agusti S (1998) The $\mathrm{CO}_{2}$ balance of unproductive aquatic ecosystems. Science 281:234-236

Dybern BI, Ackefors H, Elmgren R (1976) Recommendations on methods for marine biological studies in the Baltic Sea. Baltic Mar Biol Publ 1:1-98

Elmgren R (1984) Trophic dynamics in the enclosed, brackish Baltic Sea. Rapp P-V Réun Cons Int Explor Mer 183: 152-169

Fenchel T (1980) Relation between particle size selection and clearance in suspension-feeding ciliates. Limnol Oceanogr 25:733-738

Findlay S, Pace ML, Lints D, Cole J, Caraco NF, Peierls B (1991) Weak coupling of bacterial and algal production in a heterotrophic ecosystem. Limnol Oceanogr 36: $268-278$

Forsgren G, Jansson M (1992) Turnover of river-transported iron, phosphorus and organic carbon in the Öre estuary, northern Sweden. Hydrobiologia 235/236:585-596

Gargas E (1975) A manual for phytoplankton primary production studies in the Baltic. Baltic Mar Biol Publ 2, Water quality Institute, Hørsholm

Hagström ^̊, Azam F, Andersson A, Wikner J, Rassoulzadegan F (1988) Microbial loop in an oligotrophic pelagic marine ecosystem: possible roles of cyanobacteria and nanoflagellates in the organic fluxes. Mar Ecol Prog Ser 49:171-178

HELCOM (1990) Second periodic assessment of the state of the marine environment of the Baltic Sea, 1984-1988; background document. Baltic Sea Environ Proc 35b. Helsinki Commission, Helsinki, p 1-432

HELCOM (2002) Fourth Periodic Assessment of the State of the Baltic Marine Area, Vol 82B, The Helsinki Commission, Helsinki

Hernroth L (1985) Recommendations on methods for marine biological studies in the Baltic Sea. Mesozooplankton biomass assessment. Baltic Mar Biol Publ 10:1-32

Hessen DO (1998) Nutrient limitation and bacteria-phytoplankton interactions in humic lakes. In: Hessen DO, Tranvik LJ (eds) Aquatic humic substances ecology and biogeochemistry. Springer-Verlag, Berlin, p 285-316

Howarth RW, Michaels AF (2001) The measurement of primary productivity in aquatic ecosystems. In: Sala OJR, Mooney H, Howarth R (ed) Methods in ecosystem science. Springer-Verlag, New York, p 72-85

ICES (2001) Report of the Baltic Fisheries Assessment Working Group. Gdynia, Poland, 18-27 April 2001. ICES CM 2001/ACFM:18

Jansson M (1998) Degradation of dissolved organic matter in humic waters by bacteria. In: Hessen DO, Tranvik LJ (eds) Aquatic humic substances ecology and biogeochemistry. Springer-Verlag, Berlin, p 177-196

Johansson S (1992) Regulating factors for coastal zooplankton community structure in the northern Baltic proper. Stockholm University, Stockholm

Joiris C, Billen G, Lancelot C, Daro MH and 5 others (1982) A budget of carbon cycling in the Belgian coastal zone: relative roles of zooplankton, bacterioplankton and benthos in the utilization of primary production. Neth J Sea Res 16: $260-275$

Jonsson PR (1986) Particle size selection, feeding rates and growth dynamics of marine planktonic oligotrichous ciliates (Ciliophora: Oligotrichina). Mar Ecol Prog Ser 33: 265-277

Kankaala P, Johansson S (1986) The influence of individual variation on length-biomass regressions in three crustacean zooplankton species. J Plankton Res 8:1027-1038

Kautsky U (1995) Ecosystem processes in coastal areas of the Baltic Sea. PhD thesis, Stockholm University

Kieber RJ, Zhou RJX, Mopper K (1990) Formation of carbonyl compounds from UV-induced photodegradation of humic substances in natural waters: fate of riverine carbon in the sea. Limnol Oceanogr 35:1503-1515

Kivi K, Kuosa H, Tanskanen S (1996) An experimental study on the role of crustacean and microprotozoan grazers in the planktonic food web. Mar Ecol Prog Ser 136:59-68

Kuuppo-Leinikki P (1990) Protozoan grazing on planktonic bacteria and its impact on bacterial population. Mar Ecol Prog Ser 63:227-238

Larsson U, Hagström $\AA$ (1982) Fractionated phytoplankton primary production, exudate release and bacterial production in a Baltic eutrophication gradient. Mar Biol 67: $57-70$

Larsson U, Blomqvist S, Abrahamsson B (1986) A new sediment trap system. Mar Ecol Prog Ser 31:205-207

Leff LG, Meyer JL (1991) Biological availability of dissolved organic carbon along the Ogeechee River continuum. Limnol Oceanogr 36:315-323

Lignell R, Hiskanen AS, Kuosa H, Gundersen K, KuuppoLeinikki P, Pajuniemi R, Uitto A (1993) Fate of a phytoplankton spring bloom: sedimentation and carbon flow in the planktonic food web in the northern Baltic. Mar Ecol Prog Ser 94:239-252

Mohammadi M, Karjala L, Kuparinen J (1993) Number, biovolume and biomass of bacteria in the mud sediment of the Bothnian Sea. Aquat Fenn 23:201-208

Moran MA, Hodson RE (1994) Support of bacterioplankton production by dissolved humic substances from three marine environments. Mar Ecol Prog Ser 110:241-247

Norland S (1993) The relationship between biomass and volume of bacteria. In: Kemp PF, Sherr BF, Sherr EB, Cole JJ (ed) Handbook of methods in aquatic microbial ecology. Lewis Publishers, Boca Raton, FL, p 303-307

Pettersson C, Allard B, Boren H (1997) River discharge of humic substances and humic-bound metals to the Gulf of Bothnia. Estuar Coast Shelf Sci 44:533-541

Pitkänen H, Tamminen T, Kangas P, Huttola T and 6 others (1993) Late summer trophic conditions in the North-east Gulf of Finland and the River Neva estuary, Baltic Sea. Estuar Coast Shelf Sci 37:453-474

Rassoulzadegan F, Sheldon R (1986) Predator-prey interactions of nanozooplankton and bacteria in an oligotrophic marine environment. Limnol Oceanogr 31:1010-1021

Rassoulzadegan F, Laval-Peuto M, Sheldon RW (1988) Partitioning of the food ration of marine ciliates between picoand nanoplankton. Hydrobiologia 159:75-88

Rolff C, Elmgren R (2000) Riverine organic matter in planktonic food webs. Mar Ecol Prog Ser 197:81-101

Salonen K, Kankaala P, Tulonen T, Hammer T, James M, Metsälä TR, Arvola L (1992) Planktonic food chains of a highly humic lake: II. A mesocosm experiment in summer during dominance of heterotrophic processes. Hydrobiologia 229:143-157

Sandberg J, Elmgren R, Wulff F (2000) Carbon flows in Baltic Sea food webs - a re-evaluation using a mass balance approach. J Mar Syst 25:249-260

Sherr EB, Sherr BF (1991) Planktonic microbes: tiny cells at the base of the ocean's food webs. TREE 6:50-54

Smith SV, Mackenzie FT (1987) The ocean as a net heterotrophic system: implications from the carbon biogeochemical cycle. Glob Biogeochem Cycles 1:187-198

Stepanauskas R, Tranvik L, Leonardson L (1999) Bio- 
availability of wetland derived DON to freshwater and marine bacterioplankton. Limnol Oceanogr 44:1477-1485

Steward GF, Wikner J, Cochlan WP, Smith DC, Azam F (1993) Estimation of virus production in the sea: II. Field results. Mar Microb Food Webs 6:79-90

Stigebrandt A (1991) Computations of oxygen fluxes through the sea surface and the net production of organic matter with application to the Baltic and adjacent seas. Limnol Oceanogr 36:444-454

Straile D (1997) Gross growth efficiencies of protozoan and metazoan zooplankton and their dependance on food concentration, predator-prey weight ratio, and taxonomic group. Limnol Oceanogr 42:1375-1385

Strathmann R (1967) Estimating the organic content of phytoplankton from cell volume. Limnol Oceanogr 12: 411-418

Strayer D (1988) On the limits to primary production. Limnol Oceanogr 33:1217-1220

Tranter ED (1968) Zooplankton sampling, Vol 2. UNESCO, Paris

Tranvik L, Höfle M (1987) Bacterial growth in mixed cultures on dissolved organic carbon from humic and clearwater. Appl Environ Microbiol 53:482-488

Tuomi P, Kuuppo P (1999) Viral lysis and grazing loss of bacteria in nutrient- and carbon-manipulated brackish water enclosures. J Plankton Res 21:923-937

Uitto A, Heiskanen AS, Lignell R, Autio R, Pajuniemi R (1997) Summer dynamics of the coastal planktonic food web in the northern Baltic Sea. Mar Ecol Prog Ser 151:1-3

Editorial responsibility: Otto Kinne (Editor),

Oldendorf/Luhe, Germany
Verity PG, Villareal TA (1986) The relative food value of diatoms, dinoflagellates, flagellates, and cyanobacteria for tintinnid ciliates. Arch Protistenkd 131:71-84

Verity PG, Robertson CY, Tronzo CR, Andrews MG, Nelson JR, Sieracki ME (1992) Relationships between cell volume and the carbon content of marine photosynthetic nanoplankton. Limnol Oceanogr 37:1434-1446

Wikner J, Hagström ̊̊ (1988) Evidence for a tightly coupled nanoplanktonic predator-prey link regulating the bacterivores in the marine environment. Mar Ecol Prog Ser 50: $137-145$

Wikner J, Hagström Å (1991) Annual study of bacterioplankton community dynamics. Limnol Oceanogr 36:1313-1324

Wikner J, Hagström ^ (1999) Bacterioplankton intra-annual variability: importance of hydrography and competition. Aquat Microb Ecol 20:245-260

Wikner J, Cuadros R, Jansson M (1999) Differences in consumption of allochtonous DOC at limnic and estuarine conditions in a watershed. Aquat Microb Ecol 17:289-299

Wulff F, Pertitilä M, Rahm L (1994) Mass-balance calculations of nutrients and hydrochemical conditions in the Gulf of Bothnia, 1991. Aquat Fenn 24:121-140

Zweifel U, Norrman B, Hagström A (1993) Consumption of dissolved organic carbon by marine bacteria and demand for inorganic nutrients. Mar Ecol Prog Ser 101:22-32

Zweifel U, Wikner J, Hagström A, Lundberg E, Norrman B (1995) Dynamics of dissolved organic carbon in a coastal ecosystem. Limnol Oceanogr 40:299-305

Submitted: May 11, 2001; Accepted: September 23, 2003

Proofs received from author(s): February 24, 2004 